\title{
ANALISIS TATA KELOLA IT DENGAN DOMAIN DSS PADA INSTANSI XYZ MENGGUNAKAN COBIT 5
}

\author{
Adhie Thyo Priandika ${ }^{1}$, Donaya Pasha ${ }^{2}$, Yusma Indonesian ${ }^{3}$ \\ ${ }^{1}$ Teknologi Informasi, Universitas Teknokrat Indoensia \\ ${ }^{2}$ Sistem Informasi, Universitas Teknokrat Indonesia \\ 1,2,3 Universitas Teknokrat Indonesia; Jl. H. ZA. Pagar Alam No. 90-11 Kedaton, \\ Bandarlampung, (0721) 702022 \\ e-mail: ${ }^{1}$ adhie_thyo@teknokrat.ac.id, ${ }^{2}$ donayapasha@gmail.com, 3yusmaindonesian7@gmail.com
}

\begin{abstract}
Archiving administration documents at Bandar Lampung PTUN has carried out conventional storage models, namely information data is stored in folders and cabinets and is still recorded manually in the books of each document and disposition, so there are some obstacles, namely forgetting to record document data and arrange documents so that there is accumulation of data and loss of documents. Another obstacle is the process of finding documents and requires quite a long time due to the un centralized storage of documents and the absence of document numbering. The purpose of this research is to analyze IT governance using COBIT 5. The analytical method in this study uses the COBIT 5 freamwork using the sub domains DSS.01, DSS.02, DSS.03, DSS.04, DSS.05, and DSS.06 and uses the results of the evaluation of the maturity level of COBIT (level 0-5). The solution of IT governance analysis in PT Lampung Bandar Lampung will use COBIT 5 then it is focused on archiving documents using the DSS domain (job description), it is hoped that by doing this evaluation can meet IT processing standards, and improve service to stakeholders and provide knowledge of the results of measuring levels maturity in security in archiving documents in order to achieve company goals. 4.8 Test results that are generally applied the level of company maturity in information technology has referred to the level of best practice.
\end{abstract}

Keyword : Analysis, IT Governance, Cobit 5, document administration, framework

\begin{abstract}
Abstrak
Tata kelola administrasi pengarsipan dokumen pada PTUN Bandar Lampung telah melaksanakan model penyimpanan secara konvensional, yaitu data informasi disimpan kedalam map dan lemari dan masih dicatat secara manual didalam buku masing-masing dokumen dan disposisi, sehingga terdapat beberapa kendala yaitu lupa dalam melakukan pencatatan data dokumen dan menyusun dokumen sehingga terjadi penumpukan data dan kehilangan dokumen. Kendala lain yaitu pada proses pencarian dokumen dan memerlukan waktu yang cukup lama dikarenakan tidak terpusatnya penyimpanan dokumen dan tidak adanya penomoran dokumen. Tujuan dalam penelitian ini yaitu melakukan analisis tata kelola IT menggunakan COBIT 5. Metode analisis dalam penelitian ini menggunakan freamwork COBIT 5 dengan menggunakan sub domain DSS.01, DSS.02, DSS.03, DSS.04, DSS.05, dan DSS.06 dan menggunakan metode hasil evaluasi tingkat kematangan (maturity level) dari COBIT (level 0-5). Solusi analisis tata kelola IT pada PTUN Bandar Lampung akan menggunakan COBIT 5 maka difokuskan kepada pengarsipan dokumen dengan menggunakan domain DSS (job description), diharapkan dengan dilakukannya evaluasi ini dapat memenuhi standar pengolahan IT, dan meningkatkan pelayanan kepada stakeholder dan memberikan pengetahuan hasil dari mengukur tingkat kematangan dalam keamanan dalam pengarsipan dokumen guna dalam mencapai tujuan perusahaan. Hasil pengujian 4.8 yang diterapkan secara umum tingkat kematangan perusahaan dalam teknologi informasi sudah mengacu pada level best practice.
\end{abstract}

Kata Kunci: Analisis, Tata Kelola TI, Cobit 5, dokumen administrasi, framework 


\section{Pendahuluan}

Perkembangan Teknologi Informasi (TI) pada saat ini begitu cepat, dimana TI menciptakan hubungan yang positif terhadap strategis bisnis. Salah satu institusi yang menerapkan TI adalah Instansi Pemerintah. Penerapan TI yang baik dan berkualitas merupakan hal yang sangat penting dalam mendukung pelayanan kepada stakeholder agar prosesnya menjadi lebih efektif dan efisien [1] Pengelolaan resiko-resiko teknologi informasi dan kebutuhan akan kendali terhadap informasi telah dipahami sebagai elemen kunci dalam tata kelola instansi atau organisasi. Instansi harus memenuhi kebutuhan akan informasi dalam hal kualitas, fiduciary (kepercayaan) dan keamanan [2]

Penyimpanan merupakan salah satu produk pekerjaan kantor (office work) selain surat, formulir dan laporan. Kegiatan atau pekerjaan kantor yang berhubungan dengan penyimpanan dan pengelolaan surat menyurat dan dokumen-]dokumen ini disebut kearsipan [3].

PTUN Bandar Lampung dalam melakukan tata kelola administrasi pengarsipan dokumen telah melaksanakan model penyimpanan secara konvensional, yaitu data informasi disimpan kedalam map dan lemari dan masih dicatat secara manual didalam buku masing-masing dokumen dan disposisi, sehingga terdapat beberapa kendala yaitu lupa dalam melakukan pencatatan data dokumen dan menyusun dokumen sehingga terjadi penumpukan data dan kehilangan dokumen. Kendala lain yaitu pada proses pencarian dokumen memerlukan waktu yang cukup lama dikarenakan tidak terpusatnya penyimpanan dokumen dan tidak adanya penomoran dokumen. Dengan demikian PTUN Bandar Lampung menyadari pentingnya pengolahan tata kelola administrasi sehingga perlu adanya penerapan teknologi informasi yang dapat berkerja optimal dalam tata kelola administrasi penyimpanan dokumen.

Pengelolaan tata kelola TI ada lima yang harus diperhatikan yaitu keselarasan strategi, value delivery, manajemen sumber daya, manajemen resiko dan pengukuran kinerja. Konsep tata kelola TI telah menjadi tren dalam sektor publik di berbagai Negara, dan untuk dapat mengetahui tingkat kapabilitas dari tata kelola administrasi pengarsipan dokumen dipilih framework Control Objectives for Information and Related Technology (COBIT). Framework COBIT ini dipilih karena memiliki banyak kelebihan dan juga sangat relevan dengan alat kontrol lainnya. COBIT juga dapat memperkecil jarak antara resiko bisnis, kontrol dan masalah yang terjadi pada proses TI serta memberikan saran perbaikan untuk meningkatkan pelayanan manajemen administrasi [3].

Control Objectives for Information and Related Technology (COBIT) dapat didefinisikan sebagai alat pengendalian untuk informasi dan teknologi terkait dan merupakan standar terbuka untuk pengendalian terhadap teknologi informasi yang dikembangkan oleh Information Audit and Control Association (ISACA) melalui lembaga yang dibentuknya yaitu Information technology Governance Institute (ITGI) pada tahun 1992. Tujuan diluncurkan COBIT adalah untuk mengembangkan, melakukan riset dan mempublikasikan suatu standar teknologi informasi yang diterima umum dan selalu up to date untuk digunakan dalam kegiatan bisnis sehari-hari. Salah satu versi COBIT adalah COBIT 5.

Analisis tata kelola IT pada PTUN Bandar Lampung akan menggunakan COBIT 5 maka difokuskan kepada pengarsipan dokumen dengan menggunakan domain DSS (job description), diharapkan dengan dilakukannya evaluasi ini dapat memenuhi standar pengolahan IT, dan meningkatkan pelayanan kepada stakeholder dan memberikan pengetahuan hasil dari mengukur tingkat kematangan dalam keamanan dalam pengarsipan dokumen guna dalam mencapai tujuan perusahaan.

\section{Landasan Teori}

\subsection{Penelitian Terdahulu}

Penelitian terkait dengan sistem efiling dokumen pada sebuah desa sangat membantu bagi admin desa dalam hal mengelola dokumen yang ada pada desa [1]. Mempermudah pengarsipan dokumen dan pencarian dokumen serta memiliki sistem reminder ketika ada pembaharuan dokumen. Pengarsipan dan pencarian dokumen dalam bentuk softfile dapat dilakukan dengan mudah menggunakan handphone. Implementasi tata kelola IT juga menggunakan COBIT 5 telah diteliti pada sebuah perguruan tinggi dalam menentukan tata kelola berbasis IT yang baik[2]. Hal ini dapat diketahui domain yang dengan tingkat maturity yang rendah sehingga dapat dilakukan fokus perbaikan.

Audit sistem informasi pada perusahaan dagang aneka gemilang menggunakan COBIT juga dilakukan pada domain ensure complience with external requirement berada pada kematangan defined process, artinya bahwa perusahan telah mengetahui permasalahan yang ada dan harus segera diatasi [3]. Perusahaan juga telah menyelesaikan masalah yang ada dengan langkahlangkah yang telah ditetapkan sehingga pengelolaan proses pada perusahaan tersebut telah terorganisasi dengan baik. Gap yang ada pada tingkat user maupun manajemen tidak terlalu besar sehingga dapat dikatakan bahwa apa yang telah diharapkan oleh manajemen dapat terpenuhi.

Penilaian Terhadap Penerapan Proses IT Governance Menggunakan COBIT Versi 5 pada Domain BAI Untuk Pengembangan Aplikasi pada IPos di kantor pos Indonesia telah dilakukan dimana PT Pos Indonesia telah menjalankan standar proses berbasis teknologi informasi dengan baik[7]. Hal ini ditunjukkan dengan pemetaan antara proses COBIT dengan proses PT Pos Indonesia. Terdapat 3 proses berbasis BAI yang berada pada level 0 
(incomplete). Terdapat 7 proses berbasis BAI berada pada level 1 (performed) serta manajemen TI telah sesuai dengan peraturan BUMN yang telah ditetapkan berada pada level 3 belum tercapai.

\subsection{Analisis}

Analisis adalah sebuah kegiatan untuk mencari suatu pola selain itu analisis merupakan cara berpikir yang berkaitan dengan pengujian secara sistematis terhadap sesuatu untuk menentukan bagian, hubungan antar bagian dan hubungannya dengan keseluruhan [4]. Analisis dilakukan terhdap data yang telah diperoleh dari hasil wawancara yang telah dilakukan.

\subsection{Tata Kelola TI}

Tata kelola TI atau sering dikenal dengan IT governance diartikan sebagai struktur hubungan dan proses yang mengatur dan memberikan arah bagi organisasi dalam rangka mencapai tujuan organisasi dengan memberikan nilai tambah dari penggunaan teknologi informasi[5]. Tata kelola IT harus selaras dan mendukung tercapainya tujuan organisasi. Tata kelolal IT perlu dilakukan evaluasi pada sebuah instansi. Hal ini ditujukan untuk mengetahui Teknologi Informasi yang telah ditetapkan dan pemahaman implementasi TI dalam mencapai tujuan perusahaan termasuk proses bisnis, arsitektur TI, organisasi dan rencana pengembangan TI.

\subsection{Audit}

Audit merupakan bagian dari audit laporan keuangan, perlu dilakukan untuk memeriksa tingkat kematangan atau kesiapan suatu organisasi dalam melakukan pengelolaan teknologi informasi (IT governance) [6]. Audit ini harus dilaksanakan oleh orang yang kompeten dengan tujuan untuk mengetahui apakah organisasi telah melaksanakan standar yang telah ditetapkan dan disetujui bersama dalam mencapai tujuan organisasi. Dalam pelaksanaannya auditor TI akan mengumpulkan data dan bukti yang dibutuhkan dan memadai dengan berbagai teknik baik melalui survey, wawancara, dokumentasi dan observasi. Tujuan audit TI adalah availability atau kesediaan informasi, confidentiality atau kerahasiaan informasi, dan integrity atau apakah informasi handal dan dapat dipercaya.

Banyak manfaat yang didapatkan perusahaan jika melakukan audit TI pada perusahaan mulai dari manfaat saat sebelum implementasi dan setelah berjalan diantaranya :

1. Instansi akan dapat mengetahui apakah sistem yang telah diterapkan sudah sesuai dan telah memenuhi standar acceptance criteria

2. Instansi juga akan dapat mengetahui apakah setiap pengguna telah dapat menggunakan sistem yang telah diterapkan dengan baik

3. Instansi akan dapat mengetahui outcome yang ada apakah telah sesuai dengan yang diharapkan atau belum.

4. Instansi akan mendapatkan masukan dan saran atasi risiko yang masih ada.

5. Instansi juga mendapatkan bahan sebagai acuan dalam merencanakan pengembangan yang akan datang

6. Membantu memastikan bahwa jejak audit (audit trail) telah dapat digunakan oleh manajemen maupun pihak berwenang lainnya.

\subsection{COBIT}

COBIT 5 (Control Objectives For Information and Related Technology) dibuat berdasarkan pengalaman penggunaan COBIT selama lehih dari limabelas tahun merupakan generasi terbaru dari panduan ISACA. Framwork ini telah banyak digunakan oleh banyak perusahaan dan penggunaan dari bidang bisnis, komunitas, IT, risiko, asuransi, dan keamanan. Sejumlah tata kelola dan manajemen proses telah didefinisikan dan dijelaskan secara rinci pada COBIT 5.

COBIT 5 menyediakan kerangka kerja yang komprehensif yang membantu perusahaan dalam mencapai tujuan mereka untuk tata kelola dan manajemen aset berbasis teknologi informasi (IT) bagi perusahaan. Secara sederhana, COBIT membantu perusahaan menciptakan nilai yang optimal dari IT dengan menjaga keseimbangan antara mewujudkan manfaat dan mengoptimalkan tingkat resiko dan penggunaan sumber daya. COBIT 5 menggunakan praktik tata kelola dan manajemen untuk menjelaskan tindakan praktik yang baik untuk efek tata kelola dan manajemen lebih baik bagi perusahaan menggunakan IT. COBIT 5 tidak dimaksudkan untuk menggantikan salah satu kerangka kerja atau standar lainnya, tetapi untuk menekankan tata kelola dan manajemen serta mengintegrasikan praktik pengelolaan terbaik pada perusahaan dengan memanfaatkan dan memaksimalkan teknologi informasi [7].

\subsection{Domain COBIT 5}

COBIT 5 framework dirancang dengan 5 domain yang masing-masing mencakup penjelasan rinci dan termasuk panduan secara luas dan bertujuan sebagai tata kelola dan manajemen TI perusahaan [8]. Lima domain yang ada pad COBIT 5 adalah :

1. Evaluate, Direct and Monitor (EDM), proses pengelolaan yang berhubungan dengan pengelolaan sasaran stakeholder, nilai pengiriman, optimisasi resiko dan sumber daya, termasuk praktek dan aktivitas yang ditujukan pada pengevaluasian pilihan strategi, memberikan pengarahan IT dna pemonitoran outcome.

2. Align, Plan, and Organize (APO), domain ini meliputi penyelarasan, palnning atau perencanaan, dan pengaturan agar Teknologi Informasi (IT) dapat berkontribusi secara maksimal untuk mencapai tujuan bisnis dari organisasi,

3. Build, Acquire, and Implement (BAI), domain ini meliputi membangun, memperoleh, dan mengimplementasikan sistem yang mendukung proses bisnis, 
4. Delivery, Service and Support (DSS), meliputi mengirimkan, service atau layanan, dan dukungan atau memberi pelayanan yang aktual bagi bisnis, termasuk manajemen data dan proteksi informasi yang berhubungan dengan proses bisnis

5. Monitoring, Evaluation and Assess (MEA), domain ini terdiri dari pengawasan, evaluasi dan penalaian manajemen tentang pengendalian proses-proses, oleh lembaga monitoring yang bersifat independen dimana dapat berasal dari dalam dan luar organisasi atau lembaga alternatif lainnya yang profesional

\section{Metodologi Penelitian}

Pada penelitian ini dilakukan beberapa tahapan untuk Hasil pembahasan ini menggunakan metode pengumpulan data yaitu pengamatan, wawancara, tinjauan pustaka, dan dokumentasi.

\subsection{Kerangka Penelitian}

Dalam melaksanakan penlitian ini penulis menggunakan kerangka penelitian sebagai berikut seperti ditunjukkan pada gambar 1 .

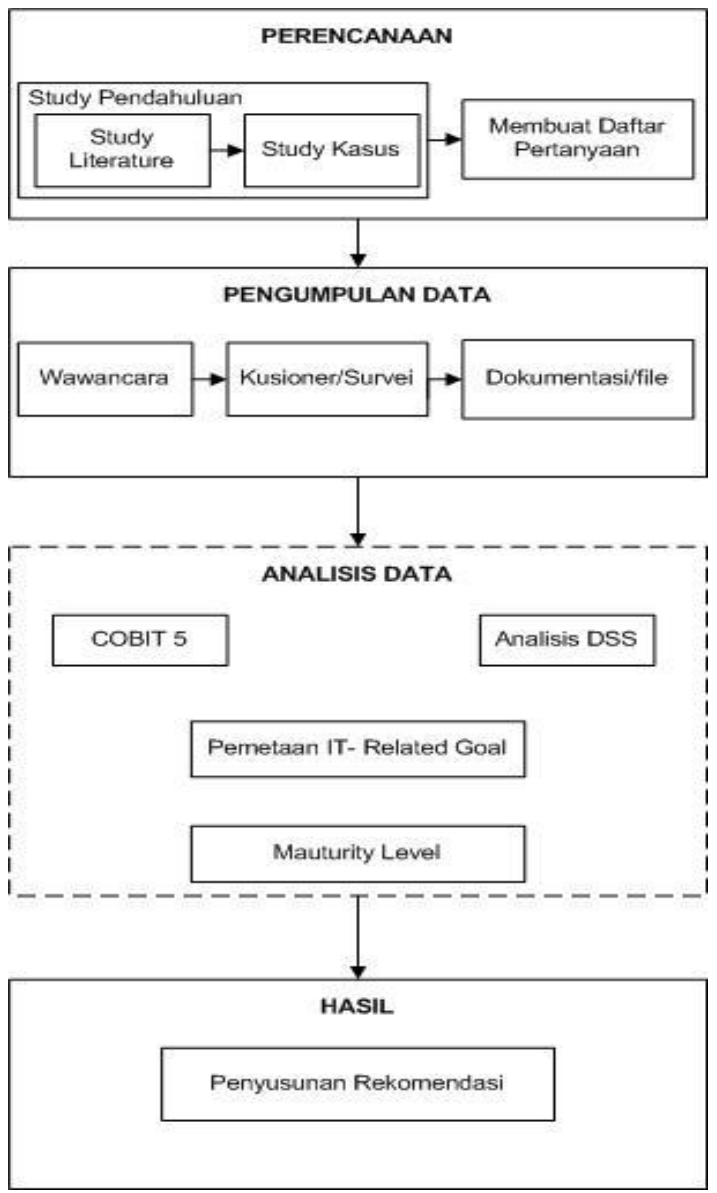

Gambar 1 Kerangka Penelitian

\subsection{Identifikasi Pemetaan Enterprise Goal dengan Tujuan Perusahaan}

Berikut ini adalah hasil pemetaan Enterprise Goal dengan tujuan perusahaan.

\begin{tabular}{|c|c|c|c|c|}
\hline \multirow[b]{2}{*}{ BSC Dimension } & \multirow[b]{2}{*}{ Enterprise Goal } & \multicolumn{3}{|c|}{ Relation to Governance Objectives } \\
\hline & & \begin{tabular}{|c} 
Benefits \\
Realisation
\end{tabular} & $\begin{array}{c}\text { Risk } \\
\text { Optimisation }\end{array}$ & $\begin{array}{c}\text { Resource } \\
\text { Optimisation }\end{array}$ \\
\hline \multirow[t]{5}{*}{ Financial } & 1. Stakeholder value of business investments & $p$ & & $S$ \\
\hline & 2. Porttolio of competitive products and services & $p$ & $p$ & $S$ \\
\hline & 3. Managed business risk (sategyarding of assets) & & $p$ & $S$ \\
\hline & 4. Complance with external laws and regulations & & $p$ & \\
\hline & 5. Financial tansparency & $p$ & $S$ & $s$ \\
\hline \multirow[t]{5}{*}{ Customer } & 6. Customer-oriented service culture & $p$ & & $S$ \\
\hline & 7. Business service continuty and avallability & & $p$ & \\
\hline & 8. Agle responses to a changing business environment & $P$ & & $S$ \\
\hline & 9. Information-based strategic decision making & $P$ & $p$ & $p$ \\
\hline & 10. Optimisation of service delivery costs & $P$ & & $p$ \\
\hline \multirow[t]{5}{*}{ Intemal } & 11. Optimisation of business process functionality & $p$ & & $p$ \\
\hline & 12. Optimisation of business process costs & $p$ & & $p$ \\
\hline & 13. Managed business change programmes & $p$ & $p$ & $S$ \\
\hline & 14. Operational and staff productivity & $p$ & & $p$ \\
\hline & 15. Compliance with internal policies & & $p$ & \\
\hline \multirow[t]{2}{*}{ Learning and Growth } & 16. Skilled and motivated peeple & $s$ & $p$ & $p$ \\
\hline & 17. Product and business innovation culture & $p$ & & \\
\hline
\end{tabular}

Gambar 2 Pemetaan Enterprise Goal dengan Tujuan Perusahaan

Pada gambar 3 berikut ini ditunjukkan pemetaan enterprise goal dengan IT related goal.

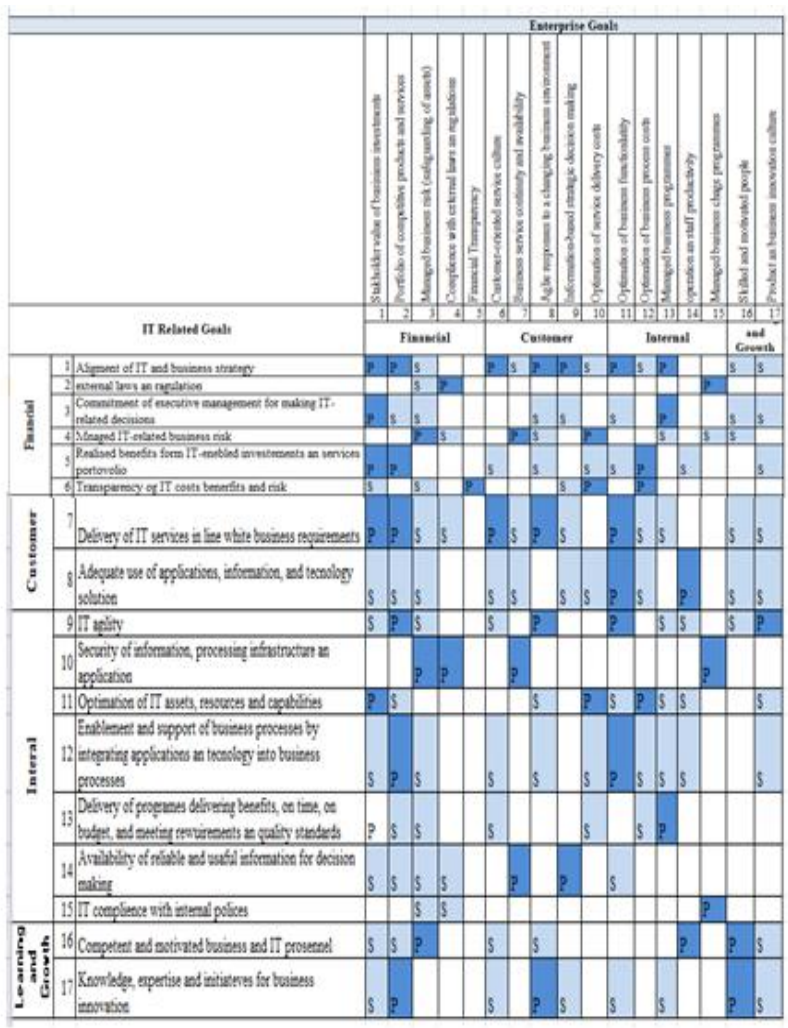

Gambar 3 Pemetaan Enterprise Goal dengan IT-Related Goal 


\subsection{Pemetaan IT-Related Goal dengan Proses Domain DSS}

Pemetaan IT related goal dengan proses domain DSS ditunjukkan pada gambar 4 berikut ini.

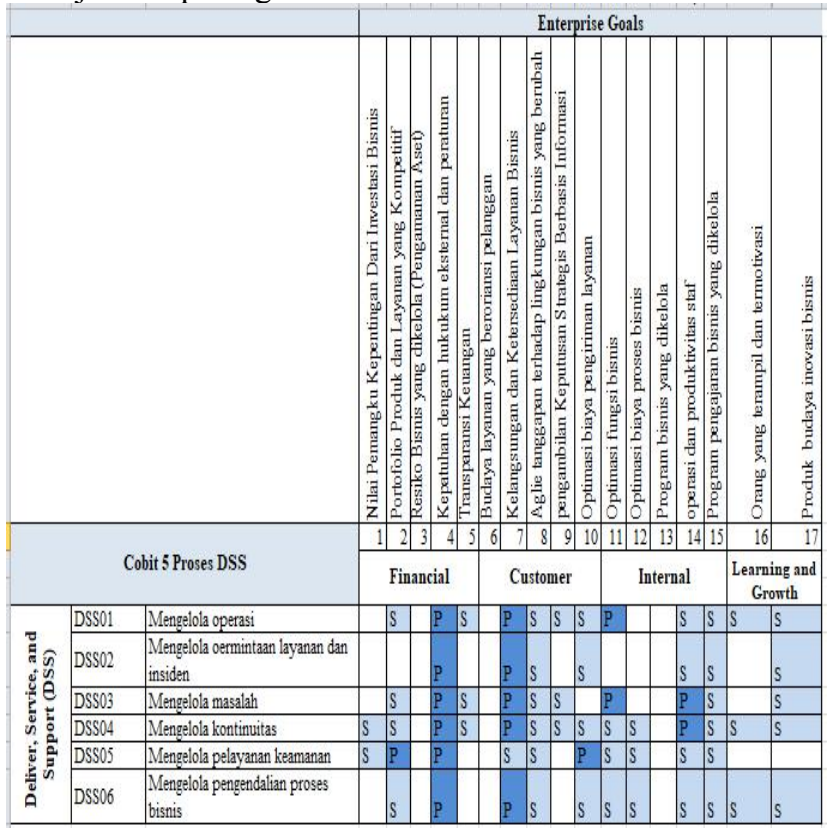

Gambar 4 Pemetaan IT-Related Goal dengan Proses Domain DSS

\section{Hasil dan Pembahasan}

Berdasarkan data yang diperoleh dari wawancara, survey dan observasi berikutnya dilakukan analisis untuk mendapatkan hasil dan kesimpulan.

\subsection{Analisis Perhitungan}

Perhitungan dilakukan berdasarkan hasil kuesioner yang dibagikan kepada karyawan PTUN Bandar Lampung, dengan menggunakan Maturity level diperoleh dengan menghitung setiap jawaban yang diberikan oleh responden dikalikan dengan bobot setiap jawaban yang telah ditentukan kemudian dibagi dengan total pertanyaan.

Pilihan jawaban yang diajukan menggunakan skala indeks sebanyak 6 jawaban yang mewakili level maturity dari CobiT (level 0-5). Rumus perhitungan nilai maturity adalah sebagai berikut [5]

$$
\text { Nilai Maturity }=\frac{\sum(\text { jawaban } x \text { bobot })}{\sum \text { pertanyaan }}
$$

Model kematangan (Maturity Level) digunakan untuk pengelolaan dan kontrol pada proses teknologi informasi didasarkan pada metode evaluasi organisasi, sehingga dapat mengevaluasi sendiri dari level tidak ada (0) hingga optimis. Model kematangan dimaksudkan untuk mengetahui keberadaan persoalan yang ada dan bagaimana menentukan prioritas peningkatan. Skala indeks tingkat kematangan COBIT dapat dilihat pada tabel 1 berikut ini.

Tabel 1. Skala Indeks Tingkat Kematangan COBIT (Kridanto, 2015)

\begin{tabular}{|l|l|}
\hline Tingkat Kematangan & Skala Pengukuran \\
\hline Skala 0-Non Existent & $0,00-0,50$ \\
\hline Skala 1-Initial / Ad Hoc & $0,51-1,50$ \\
\hline Skala 2-Repeatable but Intuitive & $1,51-2,50$ \\
\hline Skala 3-Defined & $2,51-3,50$ \\
\hline $\begin{array}{l}\text { Skala 4 Managed and } \\
\text { Measurable }\end{array}$ & $3,51-4,50$ \\
\hline Skala 5-Optimised & $4,51-5,00$ \\
\hline
\end{tabular}

\section{Kesimpulan}

Berdasarkan dari hasil analisis dan evaluasi IT pada PTUN Bandar Lampung menggunakan framework COBIT 5, maka dapat disimpulkan bahwa:

Analisis tata kelola IT dengan menerapkan COBIT 5 pada PTUN Bandar Lampung menggunakan domain DSS01 (job description) dan menggunakan sub domain DSS.01, DSS.02, DSS.03, DSS.04, DSS.05, dan DSS.06 dengan hasil evaluasi tingkat kematangan (maturity level) dengan tingkat kematangan yang berada pada level 5 (Optimised) yang berarti penerapan teknologi informasi telah memiliki ukuran dan dijadikan sebagai sasaran kinerja perusahaan. Sehingga dalam menerapkan tata kelola IT yaitu pada proses pengarsipan dokumen secara umum tingkat kematangan perusahaan dalam mengelola teknologi informasi sudah mengacu pada level bast practice.

\section{Daftar Pustaka}

[1] Damalita. 2009. Sistem Informasi Efiling Dokumen Desa Berbasis Web Studi Kasus Desa BangunPungging. Jurnal Sistem Informasi, Teknologi Informatika dan Komputer . Volume 8, Nomor 1

[2] Ajismanto Fahmi. 2017. Analisis Domain Proses COBIT Framework 5 Pada Sistem Informasi Worksheet (Studi Kasus: Perguruan Tinggi STMIK, Politeknik Palcomtech). Cogito Smart Journal. 207221

[3] Amin. 2017. Audit Sistem Informasi pada Perusahaan Dagang Aneka Gemilang Bandar Lampung Menggunakan Framework COBIT. Jurnal Informatika . 128-135.

[4] H. Surbakti. 2014. IT Governance Frameworks and COBIT 5. Edisi Pertama. Jakarta

[5] ISACA. 2012. COBIT 5 Implementation. USA: ISACA.

[6] Kridanto. 2015. Pengembangan Rencana Sistem Informasi Menggunakan Cobit 5. Gramedia. Jakarta

[7] Sitinjak, J. K., 2016. Penilaian Terhadap Penerapan Proses IT Governance Menggunakan COBIT Versi 5 pada Domain BAI Untuk Pengembangan Aplikasi 
Studi Kasus IPos di PT. Pos Indonesia. e-Proceeding of Engineerin. 5334

[8] Sugiyono. 2017. Metode Penelitian Kuantitatif Kualitatif dan R\&D. Bandung: Alfabeta

[9] Suprayitno. 2015. Audit Sistem Informasi dan Pendekatan COBIT. Mitra Wacana Media. Jakarta
[10] Wardani, S., Puspitasari, M. 2017. Audit Tata Kelola Teknologi Informasi Mengunakan Framework Cobit Dengan Model Maturity Level (Studi Kasus Fakultas ABC), Jurnal Teknologi.Vol4.No1. 